\title{
The molecular biology of von Willebrand disease
}

\author{
D. GINSBURG \\ Departments of Internal Medicine and Human Genetics and Howard Hughes Medical Institute, University of Michigan Medical \\ School, Ann Arbor, MI, USA
}

Summary. von Willebrand disease is the most common inherited bleeding disorder in humans, with the general population prevalence estimated to be as high as $1 \%$ in some studies. This condition exhibits extensive heterogeneity with over 20 distinct subtypes distinguished based on subtle clinical and laboratory differences in presentation. Recent research laboratory advances have shed considerable new light on the molecular basis of this disorder. Specific mutations within the von Willebrand factor gene have been identified in many of the qualitative variants of von Willebrand disease, providing important new insight into the structure and function of this central clotting protein. However, the complex genetic factors determining the clinical severity of type 1 von Willebrand disease, the most common variant, still remain largely unknown and are the subject of current investigation.

Keywords: von Willebrand factor, von Willebrand disease, thrombosis, haemorrhage, molecular biology, disease models, animal, DNA mutational analysis.
The first direct evidence of a molecular distinction between haemophilia A and von Willebrand disease (vWD) came from the recognition of the difference in inheritance pattern, X-linked in the case of haemophilia and autosomal dominant or recessive for $\mathrm{vWD}$. It is interesting to note that though von Willebrand did distinguish vWD from haemophilia, he incorrectly concluded that VWD is inherited in an $\mathrm{X}$-linked dominant pattern [1]. It was not until the elegant, landmark experiments of Nilsson and coworkers in 1957 that haemophilia and vWD were definitively established as due to deficiencies of distinct proteins [2].

von Willebrand factor ( $\mathrm{vWF}$ ) plays a central role in the critical initial phases of haemostasis [3-6]. The early confusion about the relationship between factor VIII (FVIII) and $\mathrm{vWF}$ stemmed from the fact that these two proteins are associated in plasma as a tight complex, with a stoichiometry of $\approx$ 50-100:1 (vWF monomer:FVIII monomer). The primary haemostatic functions of $\mathrm{vWF}$ are the formation of an adhesive link between the platelet and the vessel wall at sites of vascular injury and the localization of FVIII to these sites for subsequent participation in the coagulation cascade leading to fibrin clot deposition (Fig. 1).

vWF is produced within the endothelial cell and the megakaryocyte precursor of blood platelets (reviewed in [7]), giving rise to distinct pools of platelet, plasma, and subendothelial vWF. vWF is first synthesized as a single

Correspondence: Dr D. Ginsburg, Univ Michigan/4520 MSRB I, Howard Hughes Med Inst, 1150 W Med Cntr Dr, Ann Arbor, MI 48109-9650, USA. E-mail: ginsburg@umich.edu chain $300 \mathrm{kDa}$ precursor protein, which subsequently dimerizes and multimerizes to form high molecular weight multimers that are then secreted into plasma via both constitutive and regulated pathways. vWF in the regulated pathway is stored in specialized granules within the endothelial cell termed Weibel-Palade bodies and is secreted in response to a variety of stimuli, including treatment with DDAVP.

\section{The complexity of $\mathrm{vWD}$}

The bewildering complexity of the vWD clinical spectrum, with more than 20 subtypes described, has been

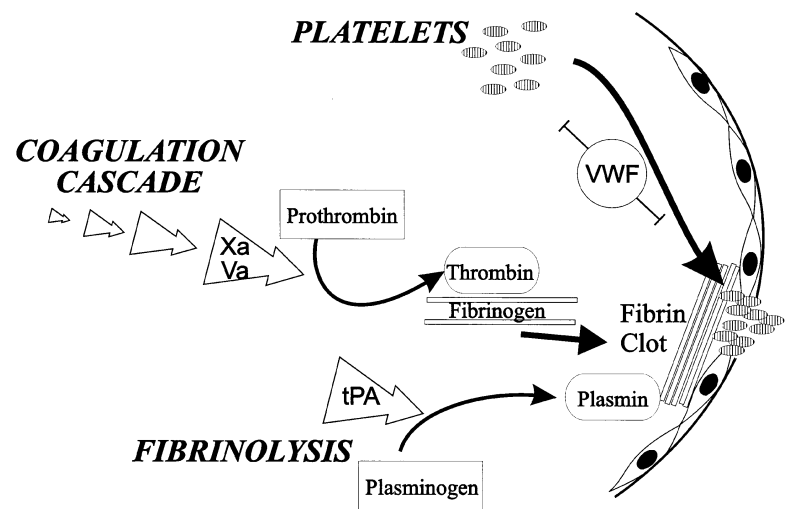

Fig. 1. Function of vWF. vWF is synthesized in endothelial cells and megakaryocytes, accounting for the free plasma and platelet $a$ granule pools, respectively. vWF provides an adhesive link between platelets and the vessel wall at sites of vascular injury and serves as a carrier for FVIII in plasma (from [4], with permission). 
made considerably more clear by recent advances in molecular genetics [4]. The newly revised classification for vWD [8] recognizes two broad categories associated with either quantitative (type 1 and type 3 ) or qualitative (type 2) deficiency of vWF.

The current classification scheme and the known genetic defects responsible for these variants are summarized in Table 1. In type 3 , or severe $\mathrm{vWD}$, very low or undetectable vWF levels are associated with severe and often life-threatening bleeding, as in the proband of the original family from the Aland Islands. Type $1 \mathrm{vWD}$ is the most common variant with a mild to moderate quantitative decrease in vWF. The most common type 2 variants, type $2 \mathrm{~A}$ and $2 \mathrm{~B}$, are associated with loss of the largest and most haemostatically active vWF multimers. Type $2 \mathrm{~N}$ vWD is due to specific defects within the FVIII binding domain of vWF. Finally, the type $2 \mathrm{M}$ classification is reserved for the remaining miscellaneous variants that do not fit well into any of the other categories.

\section{The $v W F$ gene}

The critical advance opening the door to a molecular analysis of $\mathrm{vWD}$ was the cloning of the $v W F \mathrm{cDNA}$ in 1985 by four independent groups [9-12]. The structure of the vWF protein deduced from the cDNA, and confirmed by direct amino acid sequence analysis [13], is shown schematically in Fig. 2. This summarizes a considerable body of work from multiple laboratories localizing specific functional domains within $\mathrm{vWF}$ [6]. The structure of the large and complex $v W F$ gene, as well as identification of a highly conserved partial pseudogene, was reported in 1991 by Sadler and coworkers [14]. The $v W F$ gene spans $178 \mathrm{~kb}$ on the short arm of chromosome 12 and is composed of 52 exons. The characterization of full-length $v$ WF cDNA [9] identified a large propeptide which was shown to be identical to a previously known vWF-associated protein termed VW antigen 2 [15]. As shown in Fig. 2, the FVIII binding domain within vWF has

Table 1. Classification of von Willebrand disease subtypes"

\begin{tabular}{|c|c|c|c|c|}
\hline Subtype & Frequency & Clinical features & Diagnosis & Molecular basis \\
\hline Type 3 & $1-5: 10^{6}$ & $\begin{array}{l}\text { Severe bleeding disorder: } \\
\text { autosomal recessive inheritance }\end{array}$ & $\begin{array}{l}\text { Markedly decreased or } \\
\text { undetectable vWF:Ag, } \\
\text { vWF activity and VIII:C }\end{array}$ & $\begin{array}{l}\text { vWF gene deletions, nonsense, misssense } \\
\text { and frameshift mutations throughout } \\
\text { gene; other cis-defects in mRNA } \\
\text { expression }\end{array}$ \\
\hline Type 1 & $\begin{array}{l}\text { 1-30: } 1000 \\
\text { most common } \\
\text { vWD variant } \\
(>70 \% \text { of vWD })\end{array}$ & $\begin{array}{l}\text { Mild to moderate bleeding; } \\
\text { autosomal dominant; } \\
\text { incomplete penetrance } \\
\text { (approximately } 60 \% \text { ) }\end{array}$ & $\begin{array}{l}\text { vWF:Ag, vWF activity, } \\
\text { and VIII:C all } \\
\text { proportionately decreased } \\
(20-50 \%) \text {. Normal } \\
\text { multimer distribution }\end{array}$ & $\begin{array}{l}\text { A few missense mutations reported, } \\
\text { presumed to disrupt function; some cases } \\
\text { represent heterozygous form of type } 3\end{array}$ \\
\hline Type 2A & $\begin{array}{l}\text { Approximately } \\
10-15 \% \text { of } \\
\text { clinical cases }\end{array}$ & $\begin{array}{l}\text { Mild to moderate bleeding } \\
\text { disorder; generally autosomal } \\
\text { dominant through some } \\
\text { autosomal recessive, more } \\
\text { complete penetrance than } \\
\text { type } 1 \text {; generally poor response } \\
\text { to DDAVP }\end{array}$ & $\begin{array}{l}\text { Variably decresed vWF:Ag, } \\
\text { vWF activity, and VIII:C; } \\
\text { absent high and } \\
\text { intermediate size vWF } \\
\text { multimers with prominent } \\
\text { satellite bands }\end{array}$ & $\begin{array}{l}\text { Missense mutations clustered within } \\
\text { vWF A2 repeat. Two subgroups: } \\
\text { group } 1 \text { - defect in intracellular } \\
\text { transport; group } 2 \text { - increased } \\
\text { proteolysis in plasma after secretion }\end{array}$ \\
\hline Type 2B & $\begin{array}{l}\text { Uncommon } \\
\text { variant }(<5 \% \\
\text { of clinical vWD) }\end{array}$ & $\begin{array}{l}\text { Mild to moderate bleeding } \\
\text { disorder; autosomal dominant, } \\
\text { more complete penetrance than } \\
\text { type } 1 ; \text { ? DDAVP } \\
\text { contraindicated }\end{array}$ & $\begin{array}{l}\text { Variably decreased vWF } \\
\text { antigen vWF antigen and } \\
\text { VIII:C; loss of large } \\
\text { multimers; enhanced RIPA; } \\
\text { GP1b thrombocytopenia }\end{array}$ & $\begin{array}{l}\text { Missense mutations clustered in } \mathrm{vWF} \\
\text { A1 repeat result in increased or } \\
\text { spontaneous binding to platelet }\end{array}$ \\
\hline Type $2 \mathrm{M}$ & $\begin{array}{l}\text { Rare } \\
\text { (case reports) }\end{array}$ & $\begin{array}{l}\text { Variable bleeding disorder; } \\
\text { autosomal dominant }\end{array}$ & $\begin{array}{l}\text { Variably decreased vWF:Ag } \\
\text { and VIII:C. vWF activity } \\
\text { decreased relative to antigen } \\
\text { despite presence of large and } \\
\text { intermediate multimers }\end{array}$ & $\begin{array}{l}\text { Missense mutations and small in frame } \\
\text { deletions in vWF A1 repeat }\end{array}$ \\
\hline Type $2 \mathrm{~N}$ & $\begin{array}{l}\text { Uncommon: } \\
\text { heterozygotes } \\
\text { may be } \\
\text { prevalent in } \\
\text { some } \\
\text { populations }\end{array}$ & $\begin{array}{l}\text { Variable bleeding disorder. } \\
\text { Homozygotes (or compound } \\
\text { heterozygotes) may resemble } \\
\text { autosomal haemophilia A. } \\
\text { Coinheritance may modify } \\
\text { severity of type } 1\end{array}$ & $\begin{array}{l}\text { Variable vWF:Ag and vWF } \\
\text { activity. Disporportionately } \\
\text { low VIII:C. Generally normal } \\
\text { multimers. Decreased or } \\
\text { absent vWF binding to FVIII }\end{array}$ & $\begin{array}{l}\text { Missense mutations within the N- } \\
\text { terminus of mature vWF } \\
\text { which interfere with FVIII binding }\end{array}$ \\
\hline
\end{tabular}

Reproduced from [4] with permission. 

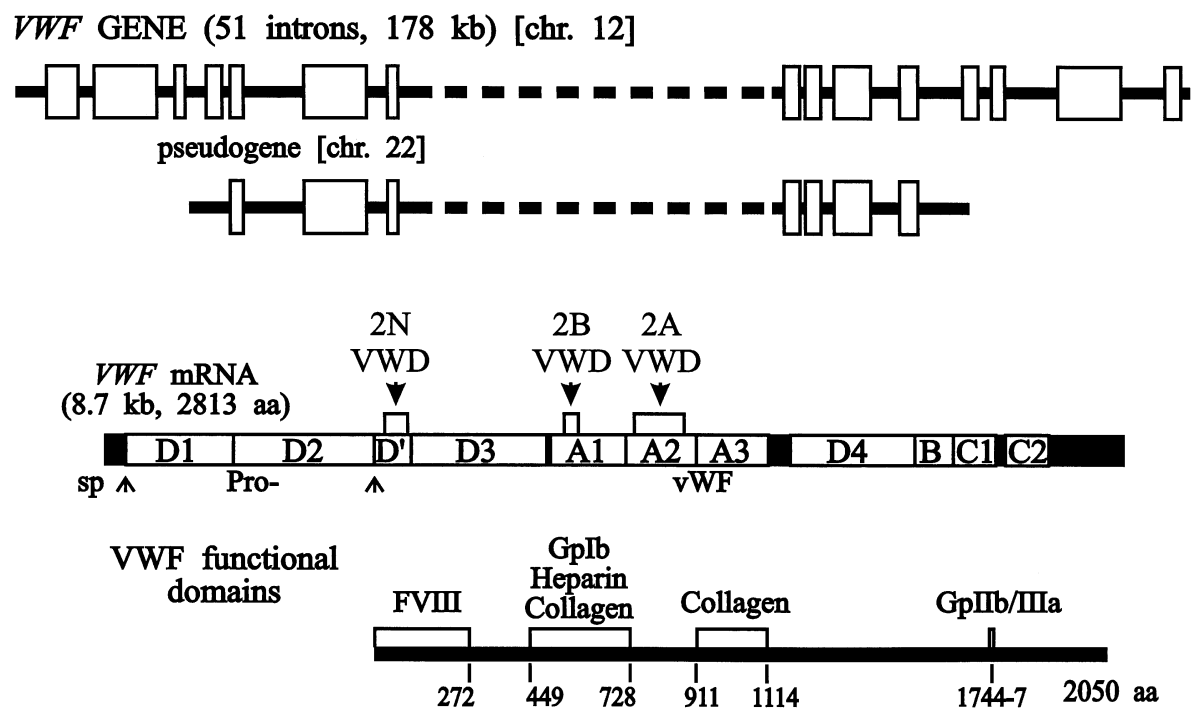

Fig. 2. The $v W F$ gene, mRNA, and protein. The $v W F$ gene and pseudogene are depicted at the top, with the boxes representing exons and solid black lines introns. The $v$ WF mRNA encodes the full prepro-vWF protein, as shown in the middle. The locations of signal peptide (sp) and propeptide (Pro-)cleavage sites are indicated by arrowheads. The lettered boxes denote the series of repeated homologous segments. The approximate localizations for known vWF functional domains within the mature vWF sequence are indicated at the bottom. Numbers beneath the domains refer to amino acid residues within the mature vWF subunit. The general location of mutations associated with the most common type 2 variants of $\mathrm{VWD}$ are depicted above the mRNA structure (adapted from [50] with permission).

been localized to an N-terminal 272 amino acid segment and the primary binding domain for the platelet receptor glycoprotein $1 \mathrm{~b}$ has been mapped to the A1 repeat. The primary collagen binding domain appears to lie within the A3 domain whereas the RGDS sequence recognized by integrins, such as the GpIIbIIIa platelet receptor, is near the C-terminal end of the protein.

\section{Molecular basis of vWD}

Figure 3 illustrates the general molecular mechanisms that should be considered when examining the molecular basis of any genetic disease, including vWD. Perhaps the most obvious way to inactivate a gene is by deletion of a portion or all of the gene sequence itself. In the common genetic disorder $\alpha$-thalassaemia, gene deletions account for the vast majority of patients. Although gene deletions have been identified in a small subset of type $3 \mathrm{vWD}$ patients, this appears to be a relatively rare mechanism for $\mathrm{vWD}$. As expected, $\mathrm{vWD}$ gene deletion is generally associated with a quantitative deficiency of vWF, though a single inframe deletion removing all three A domains has been reported in a patient with a type 2 variant [16].

A gene can also be inactivated by a single nucleotide substitution or point mutation, or the insertion or deletion of a few nucleotides within the DNA sequence. Mutations of this type can result in the substitution of a single amino acid (a missense mutation), an abrupt disruption of the coding sequence of the gene by introduction of a new stop codon (nonsense mutation), or a change in the reading frame (frameshift mutation). Small mutations of this type can also block the proper expression of the mRNA, either by interfering with normal RNA processing or transcription of the gene. Many of these mutations will result in loss of $v W F$ expression from the mutant allele due to decreased or absent mRNA, or expression of an unstable or non-functional protein. However, missense mutations can also yield a stable vWF protein with a qualitative abnormality. Indeed, missense mutations are the underlying molecular basis for most of the qualitative (type 2) $\mathrm{vWD}$ variants.

Finally, it is important to keep in mind the possibility that mutations in other genes outside of the $v$ WF locus itself may interfere with vWF function, leading to $\mathrm{vWD}$. This latter possibility can be addressed by performing linkage analysis, as illustrated at the bottom of Fig. 3. The latter approach uses polymorphism in or near the $v W F$ gene to trace the inheritance of the various $v W F$ alleles within a specific family. A strong correlation between a specific $v W F$ allele and $\mathrm{VWD}$ provides a clear indication that the disease in that family is due to a mutation within the $\mathrm{vWF}$ gene, even without knowing the precise nature of the mutation itself. Alternatively, occurrence of the same vWD phenotype in individuals in the same family who have not inherited a common copy of the $v$ WF gene would strongly suggest a contribution from another gene. 

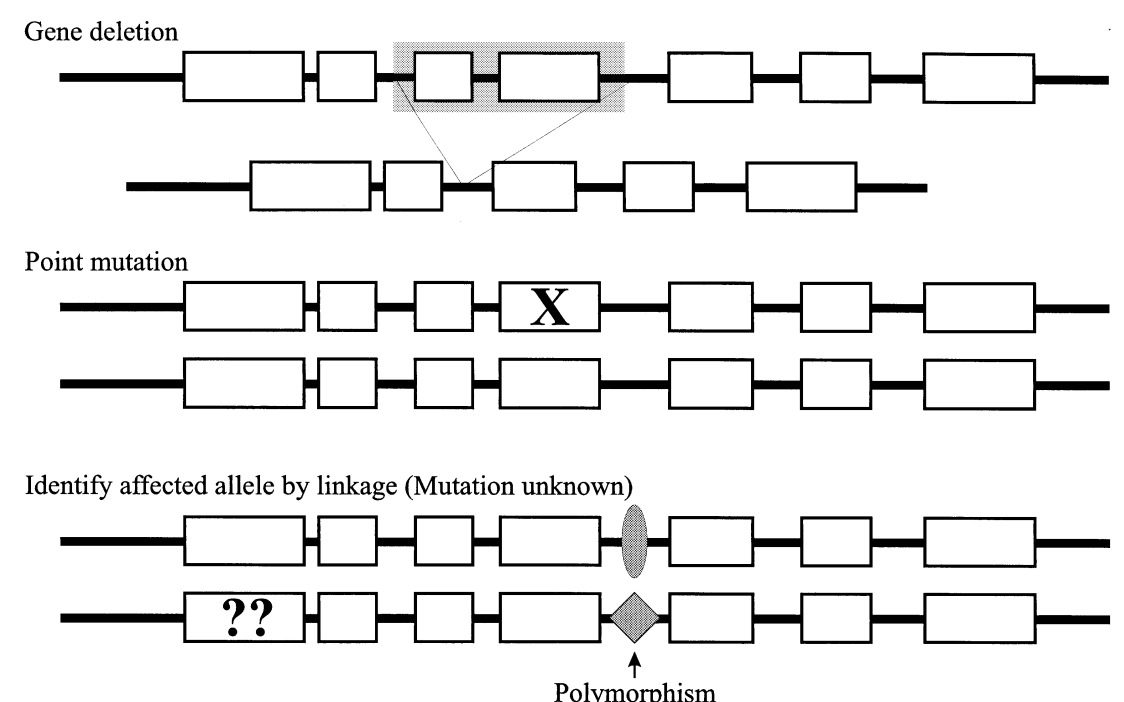

Fig. 3. Identification of DNA mutations responsible for genetic disease. Potential mechanisms responsible for genetic diseases such as $\mathrm{vWD}$ are depicted here. At the top, a gene deletion removing part or all of the gene will result in an obvious disruption of gene function. Such deletions, or more complex rearrangements of DNA, can often be detected by Southern blotting. Point mutations resulting in single nucleotide substitutions or smaller insertions or deletions within the DNA sequence can disrupt the function of the gene in a variety of ways, as described in the text. Finally, unknown mutations within the gene can be traced by linkage analysis, following the inheritance of a polymorphic DNA variation within or near the gene in members of families with the disease. A strong correlation between the specific $v W F$ allele and the disease suggest that a mutation somewhere in the gene is responsible for the disorder. Alternatively, absence of such a correlation in a sufficiently large family would indicate that the disease is due to a mutation in another gene located elsewhere within the genome.

Though the contributions of other genes outside of the $v W F$ locus to $\mathrm{vWD}$ is a subject of intense interest for our own research laboratory and others, it is important to stress that all of the limited studies that have been performed to date in classic vWD pedigrees have been consistent with linkage to the $v W F$ gene [17].

The first genetic defect to be identified in patients with vWD were large gene deletions associated with type 3 vWD [18]. The advent of the polymerase chain reaction, which made it possible to amplify and sequence small amounts of vWF mRNA from peripheral blood platelets, led to the identification of the first point mutations in the $v W F$ gene in two type $2 \mathrm{~A} v \mathrm{WD}$ pedigrees [19]. Since that time, a large number of mutations have been identified, accounting for most of the common qualitative (type 2) variants of $\mathrm{VWD}$ and these findings have had important implications for our understanding of $\mathrm{vWF}$ structure and function, as illustrated in Fig. 2. The known mutations have been periodically reviewed and catalogued [4 20]; and an updated database is maintained on the World Wide Web by an international consortium of scientists (http://mmg2.im.med.umich.edu/vWF).

\section{Type 2 A vWD}

As illustrated in Fig. 2, the vast majority of type $2 \mathrm{~A} v \mathrm{vD}$ mutations are confined to the A2 domain. One of these mutations, Arg834Trp, is particularly common, account- ing for $\approx 1 / 3$ of type $2 \mathrm{~A}$ vWD patients. The characteristic type $2 \mathrm{~A}$ vWD phenotype, loss of large and intermediate size vWF multimers, can arise via two distinct mechanisms [21], as illustrated in Fig. 4. In group 1 type $2 \mathrm{~A} v \mathrm{VWD}$, the responsible mutation results in an improperly folded protein that is retained in the endoplasmic reticulum (ER) by the cell quality control machinery. In a heterozygous patient who carries one
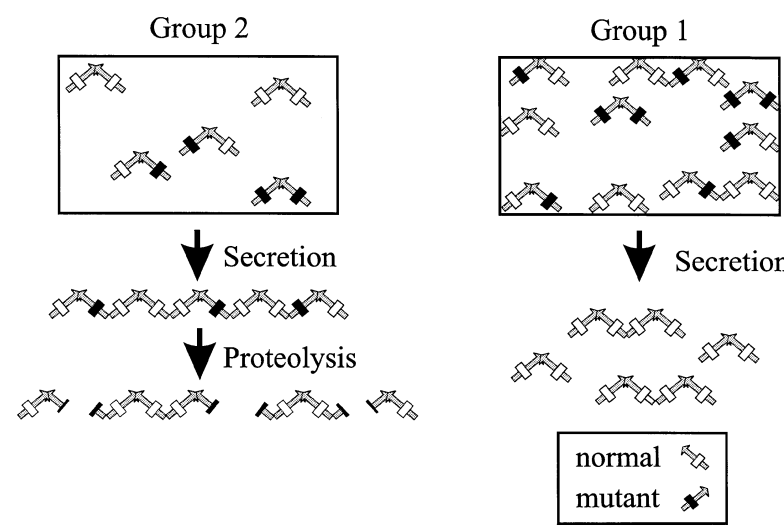

Fig. 4. Alternative mechanisms for loss of large multimers in type $2 \mathrm{~A}$ $\mathrm{vWD}$. In group 1, mutant $\mathrm{vWF}$ subunits are retained within the ER and only lower molecular weight homomultimers of normal subunits are efficiently secreted. In group 2 , heteromultimers of normal and mutant subunits are secreted, but subsequently degraded to smaller multimeric species by proteolysis in plasma. (Reproduced with permission from [7].) 
normal and one mutant copy of the gene, the larger vWF multimers, would be more likely to contain one or more mutant subunit. As a result, the largest multimers are retained in the ER and only the smallest multimers, presumably containing only the normal subunits, are secreted from the cell, accounting for the characteristic plasma vWF multimer pattern. This mechanism also accounts for the dominant inheritance of type $2 \mathrm{~A} v \mathrm{vD}$.

In group 2, an entirely different mechanism is responsible for the dominant loss of large vWF multimers. Group 2 type 2 A vWF is normally secreted from the cell. However, the mutant subunits have an increased susceptibility to cleavage by a specific metalloproteinase present in plasma. This protease cleaves normal vWF between Tyr842 and Met843 [22]. Alterations in this process appear to account for the unusually large $\mathrm{vWF}$ multimers present in the plasma of patients with TTP [23, 24]. Group 2 type $2 \mathrm{~A}$ vWF is cleaved more readily by this protease resulting in loss of the largest multimers, again most likely to contain multiple mutant subunits. The resulting plasma $\mathrm{vWF}$ multimer pattern also shows loss of the largest and intermediate size multimers characteristic of type 2 A vWD, but by this second mechanism.

Why some mutations result in group 1 and others in group 2 type $2 \mathrm{~A} v \mathrm{WD}$ is unknown. We hypothesize that both mechanisms may result from disturbance of the same specific structural motif within the A2 domain. When this structure is severely disrupted, the misfolded protein is recognized and retained within the ER. More subtle alterations may escape the cell quality control machinery but then render the protein more susceptible to proteolysis. Consistent with this hypothesis, similar amino acid substitutions can cause either group 1 or group 2 type $2 \mathrm{~A}$ vWD. For example, substitution of Glu at Gly742 results in group 2 type $2 \mathrm{~A} v \mathrm{WD}$ whereas substitution of Arg at the same position causes a group 1 phenotype.

\section{Type 2 B vWD}

The molecular mechanism responsible for type $2 \mathrm{~B}$ vWD is distinct from that of type $2 \mathrm{~A}$, though the phenotype is again characterized by loss of large vWF multimers. In type $2 \mathrm{~B} \mathrm{vWD}$, the mutation, generally resulting in a single amino acid substitution, leads to increased affinity of vWF for its platelet receptor, GPIb, often associated with spontaneous binding. The resulting vWF platelet complexes are cleared rapidly from plasma, usually resulting in mild thrombocytopenia as well as loss of the largest, most haemostatically active vWF multimers. As shown in Fig. 2, the vast majority of type $2 \mathrm{~B}$ vWD mutations are confined to the A1 repeat, helping to define the GPIb binding domain within vWF. Indeed, four specific mutations within a 35 amino acid segment of the A1 domain account for $\approx 90 \%$ of type $2 \mathrm{~B} \mathrm{vWD}[25,26]$. The insights gained from molecular studies have led to the reclassification of type 1 Malmö and type 1 New York as type $2 \mathrm{~B}$ variants. These two disorders have been shown to be due to the same mutation in the vWF A1 domain [27]. Though quite similar to other type $2 \mathrm{~B}$ mutations, the resulting alteration of $\mathrm{vWF}$ function is more subtle and the vWF plasma multimers may appear normal, hence the earlier misclassification as a type 1 variant.

\section{Type $2 \mathrm{~N}$}

As summarized in Table 1, the type $2 \mathrm{~N}$ variant is associated with decreased $\mathrm{vWF}$ affinity for FVIII, resulting in disproportionately low FVIII levels in plasma [28]. This phenotype results from the dependence of FVIII on binding to $\mathrm{vWF}$ to ensure its stability in plasma. The mutations responsible for type $2 \mathrm{~N}$ vWD are generally confined to the N-terminal segment of $\mathrm{vWF}$, helping to further define this critical functional domain within the protein.

Our group was the first to identify the Arg91 to Gln mutation, the most common cause of type $2 \mathrm{~N}$ vWD [29]. Indeed, our findings in the initial patient are instructive for the issues that should be kept in mind when evaluating missense mutations potentially associated with vWD. This patient exhibited disproportionately reduced levels of FVIII, most likely in conjunction with type $1 \mathrm{vWD}$ (though the mechanism for the latter defect has not yet been characterized in this patient). The disproportionately low FVIII levels led us to sequence the FVIII binding domain by PCR amplification of patient DNA. This analysis identified two mutations in this region, Arg91Gln on one chromosome and Arg89Gln on the other! The remarkable similarity between these two amino acid substitutions initially left us puzzled as to whether one, both, or neither was actually responsible for the decreased FVIII binding. However, functional analysis of recombinant protein carrying each of these mutations demonstrated that the Arg89Gln mutation had no effect on FVIII binding whereas binding was markedly decreased by the Arg91Gln mutation. Consistent with this observation, screening of a large number of normal individuals demonstrated that the Arg89Gln mutation is a common polymorphism in the general population whereas Arg91Gln was only observed in the patient and none of the control samples. This particular mutation is found in over $50 \%$ of type $2 \mathrm{~N}$ patients and may be particularly common in some populations [30]. This mutation, along with most of the other reported type $2 \mathrm{~N}$ mutations, does not result in complete disruption of FVIII binding and in homozygous patients is associated with residual levels of FVIII in the range of $5 \%$. Thus, type $2 \mathrm{~N}$ vWD should be in the differential diagnosis for patients with mild or moderate haemophilia $\mathrm{A}$, but is generally not confused 
with severe haemophilia A. However, a recent report [31] identified a Glu24Lys mutation in a patient with $\approx 1 \%$ FVIII levels, raising the concern that this diagnosis should also be considered in more severely affected patients.

Type $2 \mathrm{~N}$ vWD provides an instructive example of locus heterogeneity; that is identical disease phenotypes due to mutations in different genes. The distinction between classic haemophilia $\mathrm{A}$ and type $2 \mathrm{~N}$ vWD is evident from the different inheritance patterns (X-linked recessive vs. autosomal recessive), though these diseases may have very similar clinical presentations and laboratory values. Indeed, it is likely that some previous reports of apparent haemophilia $\mathrm{A}$ in females or with an unusual inheritance pattern, may have been due instead to type $2 \mathrm{~N}$ vWD. These disorders can now be distinguished by a vWF FVIII binding assay, which is available in specialized clinical laboratories, particularly in Europe. As for the type $2 \mathrm{~A}$ and $2 \mathrm{~B}$ variants discussed above, direct DNA mutation detection has the potential to be of great clinical value but is not yet routinely available.

\section{Type 1 and Type 3 vWD}

The quantitative variants of $\mathrm{vWD}$, type 1 and type 3 , are clinically the most important. Type 3 is the most severe form and accounts for the majority of patient that require frequent or intensive medical care. Type $1 \mathrm{vWD}$, though generally mild, is by far the most common, accounting for $\sim 70 \%$ of all cases of $\mathrm{vWD}$. The prevalence of type 3 vWD has been estimated at $\approx 1: 1000000$ [32-34], though it may be higher in Scandinavia. A number of mutations have been identified in type $3 \mathrm{vWD}$ patients including rare gene deletions as discussed earlier. The most common mutation is a deletion of a single nucleotide in a run of 6 cytosines in exon 18, resulting in a frameshift. This mutation was first reported by Blombäck and coworkers and has been identified in a number of type 3 alleles in Scandinavia, including the original Åland Island pedigree [35-37].

What is the relationship between type $1 \mathrm{vWD}$ and type 3 ? The simplest explanation is that type $1 \mathrm{vWD}$ represents the heterozygous or carrier state for type $3 \mathrm{vWD}$. A mutation that inactivate the $v W F$ gene will result in markedly reduced or absent vWF levels in the homozygote, leading to type $3 \mathrm{vWD}$. In the heterozygote, the presence of one inactivated and one normal allele should lead to vWF levels that are approximately half normal, resulting in mild bleeding. Though this may be the case in some type 1 patients, there are several problems with this simple explanation. First, in type $3 \mathrm{vWD}$, the inheritance is frequently described as 'recessive' with the obligate carrier parents having no bleeding symptoms and often entirely normal vWF levels. In addition, the prevalence of type $1 \mathrm{vWD}$ from epidemiological studies (as high as 1-
3\% [38 39]); would be predicted to lead to a much higher frequency of severe type $1 \mathrm{vWD}$ than is observed.

The frequent lack of the manifestations of type $1 \mathrm{vWD}$ among type 3 carriers may be explained by incomplete penetrance. Penetrance is the portion of individuals who carry the causative genetic mutation that exhibit the typical signs and symptoms of the disease. From evaluation of large pedigrees with type $1 \mathrm{vWD}$ [40], the penetrance of the disease is estimate at $\approx 60 \%$ of obligate mutation carriers. It is likely that the penetrance of type 1 vWD is significantly lower in unselected populations. Taking this penetrance figure into account, the true frequency of $v W F$ gene mutation carriers could be considerably higher than the $1-3 \%$ estimated prevalence figures cited above, and even more incompatible with the observed frequency of type $3 \mathrm{vWD}$. These inconsistencies may be explained in part by over-diagnosis of type $1 \mathrm{vWD}$ when based primarily on laboratory values, with some 'patients' perhaps simply representing the edge of the normal distribution. Though it is also possible that some cases of type $1 \mathrm{vWD}$ may be due to mutations at another genetic locus, as noted above, the limited linkage studies that have been published to date are all consistent with linkage to the $v W F$ gene [17].

It is also possible that specific type $3 \mathrm{vWD}$ alleles cause symptoms in carriers, whereas other are silent. Our group has noted an association of gene deletions and other genetic defects leading to loss of $v W F$ mRNA with recessive inheritance in type 3 families. In contrast, such alleles that are null at the mRNA level may be less frequent in type 1 families [17, 41]. Perhaps mRNA null mutations can be compensated for by increased production of vWF from the normal allele. Alternatively, the presence of an mRNA from the vWD allele may indicate a corresponding mutant protein that interfere with the expression of $\mathrm{vWF}$ from the normal allele. Eikenbloom and coworkers [42] have demonstrated such a dominant negative effect from mutation of a cysteine residue in the D3 domain of vWD. However, expression studies of the common exon 18 frameshift mutation failed to identify a similar mechanism for this allele, even though it is associated with both type 3 and type $1 \mathrm{vWD}$ in the original Åland pedigree [37].

\section{Other genetic factors as modifiers of plasma vWF level}

A number of genetic and environmental factors are likely to contribute to the wide variability in clinical severity among type $1 \mathrm{vWD}$ patients. Environmental variables such as thyroid hormone, oestrogen level, and stress are all know to significantly modify plasma vWF levels [17]. In addition, genetic studies suggest that $\approx 60 \%$ of the variation in plasma vWF levels is determined by genetic 


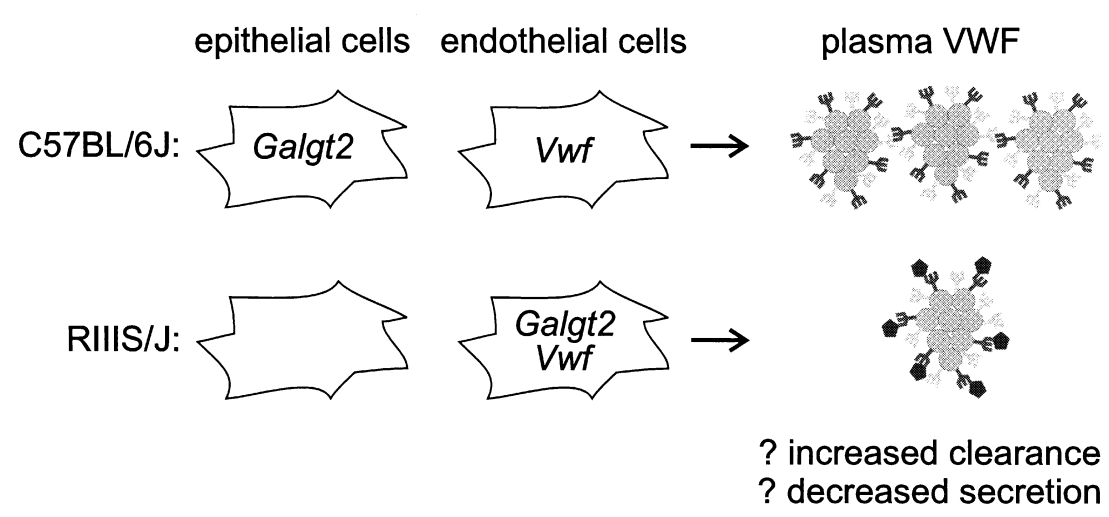

Fig. 5. Model for mechanism of Mvwf action. In most mouse strains, Galgt2 is expressed primarily in intestinal epithelial cells and Vwf is expressed in vascular endothelial cells. vWF secreted from endothelial cells circulates in the plasma at normal steady-state levels. However, in RIIIS/J mice, Galgt2 expression is switched from epithelial to endothelial cells, leading to the transfer of GalNAc (black pentagons) onto oligosaccharides present on vWF. The novel sugar structure on the secreted vWF results in decreased steady-state plasma levels, either through interference with the secretory pathway or more rapid clearance of $\mathrm{vWF}$ from plasma. (Reproduced with permission from [49].)

factors [43]. ABO blood group accounts for about 30\% of this genetic effect, with plasma vWF levels in type $\mathrm{O}$ individuals $25-35 \%$ lower than in non-O individuals [44]. Thus, it appears likely that there are a number of other genetic factors that could have a dramatic effect on plasma vWF levels that, when taken together with ABO and environmental effects, could account for the wide variation in clinical severity and incomplete penetrance of type $1 \mathrm{vWD}$. It is also possible that a subset of type $1 \mathrm{vWD}$ patients may have a combination of genetic modifier mutations without any defect at the $v W F$ gene itself. This hypothesis has important implications for the diagnosis and treatment of $\mathrm{vWD}$.

Our laboratory has recently employed the mouse as a model system in which to study genetic modifying effects on plasma vWF levels. We have been studying the RIIIS/J inbred mouse strain first identified by Sweeney and coworkers [45] as a model for type $1 \mathrm{vWD}$. When compared to the common inbred strain C57BL6/J, RIIIS/J mice have plasma vWF levels that are $\approx 50 \%$ of normal, with a normal multimer distribution. We initially showed that this alteration was not related to a defect within the $v W F$ gene [46] and subsequently went on to identify the responsible gene as a novel genetic locus on mouse chromosome 11 [47,48]. We have recently succeeded in identifying the responsible modifier gene, which we have termed Mvwf for modifier of vWF, as a previously known genetic locus, Galgt2 [49]. GALGT2 is a glycosyltransferase enzyme which transfers GalNac residues to a specific location on growing carbohydrate structures of both $\mathrm{N}$ - and O-linked sugars. The novel molecular mechanism we identified as responsible for the low vWF level in RIIIS/J may have important implication, not only for $\mathrm{vWF}$, but also for genetic modification for a number of other plasma proteins.
The mechanism responsible for the Mvwf phenotype is illustrated in Fig. 5. Normally Galgt2 is expressed primarily in the gut epithelial cell. The mutation in RIIIS/J turns off expression of this gene in the gut and instead turns it on in the entire vascular endothelial cell bed, the site of plasma vWF synthesis. Thus, the mutation in this disorder does not alter the GALGT2 protein structure itself, but rather changes its expression pattern. Expression of GALGT2 at the site of $\mathrm{vWF}$ synthesis results in a unique sugar structure not normally present on vWF. The altered vWF is rapidly cleared from plasma, with a half life of $\approx 10 \mathrm{~min}$, compared to the normal $\approx 4-8 \mathrm{~h}$ of wild-type $\mathrm{vWF}$. This results in a marked decrease in plasma vWF levels, as much as 20 -fold (to $5 \%$ ) when compared to certain wild mouse strains [49].

The Mvwf molecular mechanism identified in the RIIIS/J mouse provides a potential explanation for a possible subset of type $1 \mathrm{vWD}$ unrelated to the $v W F$ gene itself. It is unlikely that this unique and unusual mutation mechanism has also occurred independent in humans as a cause of human type $1 \mathrm{vWD}$. However, the general paradigm of altered protein processing determined by variation at other genes could certainly apply to human $\mathrm{VWD}$, as well as diseases due to alterations in other plasma proteins. Continued advances in understanding the complex determinants of plasma vWF level should dramatically improve our future ability to precisely diagnose and classify this common human bleeding disorder.

\section{Acknowledgment}

This work was supported by NIH grant \#RO1HL39693. D.G. is an Investigator of the Howard Hughes Medical Institute. 


\section{References}

1 von Willebrand EA. Hereditär Pseudohemofili. Finska Läkarsällskapetes Handl 1926; 67: 7.

2 Nilsson IM, Blombäck M, Jorpes E, Blombäck B, Johansson S-A. v. Willebrand's disease and its correction with human plasma fraction 1-0. Acta Med Scand 1957; 159: 179.

3 Ginsburg D. Hemophilia and other inherited disorders of hemostasis and thrombosis, In: Rimoin DL, Connor JM, Pyeritz RE, Emery AEH, eds. Emery and Rimoin's Principles and Practice of Medical Genetics, New York, Churchill Livingstone, 1997: p 1651.

4 Nichols WC, Ginsburg D. von Willebrand disease. Med 1997; 76: 1.

5 Sadler JE. Biochemistry and genetics of von Willebrand factor. Annu Rev Biochem 1998; 67: 395.

6 Ruggeri ZM, Ware J, Ginsburg D. von Willebrand factor. In: Loscalzo J, Schafer AI, eds. Thrombosis and Hemorrhage, 1998: p 337.

7 Wagner DD, Ginsburg D. Structure, biology and genetics of von Willebrand protein. In: Benz EJ Jr, Shattil SJ, Furie B, Cohen HJ, eds. Hematology: Basic Principles and Practice, 1994: p 1717.

8 Sadler JE. A revised classification of von Willebrand disease. Thromb Haemost 1994; 71: 520.

9 Ginsburg D, Handin RI, Bonthron DT et al. Human von Willebrand factor (vWF): isolation of complementary DNA (cDNA) clones and chromosomal localization. Sci 1985; 228: 1401.

10 Sadler JE, Shelton-Inloes BB, Sorace JM, Harlan JM, Titani $\mathrm{K}$, Davie EW. Cloning and characterization of two cDNAs coding for human von Willebrand factor. Proc Natl Acad Sci USA 1985; 82: 6394.

11 Verweij CL, de Vries CJM, Distel B et al. Construction of cDNA coding for human von Willebrand factor using antibody probes for colony-screening and mapping of the chromosomal gene. Nucl Acids Res 1985; 13: 4699.

12 Lynch DC, Zimmerman TS, Collins CJ et al. Molecular cloning of cDNA for human von Willebrand factor: authentication by a new method. Cell 1985; 41: 49.

13 Titani K, Kumar S, Takio K et al. Amino acid sequence of human von Willebrand Factor. Biochem 1986; 25: 3171.

14 Mancuso DJ, Tuley EA, Westfield LA et al. Human von Willebrand factor gene and pseudogene: Structural analysis and differentiation by polymerase chain reaction. Biochem 1991; 30: 253.

15 Fay PJ, Kawai Y, Wagner DD et al. Propolypeptide of von Willebrand factor circulates in blood and is identical to von Willebrand antigen II. Sci 1986; 232: 995.

16 Bernardi F, Patracchini P, Gemmati D et al. In-frame deletion of von Willebrand factor A domains in a dominant type of von Willebrand disease. Hum Mol Genet 1993; 2: 545.

17 Mohlke KL, Ginsburg D. von Willebrand disease and quantitative deficiency of von Willebrand factor. J Lab Clin Med 1997; 130: 252.

18 Shelton-Inloes BB, Chehab FF, Mannucci PM, Federici AB, Sadler JE. Gene deletions correlate with the development of alloantibodies in von Willebrand Disease. J Clin Invest 1987; 79: 1459 .
19 Ginsburg D, Konkle BA, Gill JC, et al. Molecular basis of human von Willebrand's disease: analysis of platelet von Willebrand factor mRNA. Proc Natl Acad Sci USA 1989; 86: 3723-7.

20 Ginsburg D, Sadler JE. von Willebrand Disease: a database of point mutations, insertions, and deletions. Thromb Haemost 1993; 69: 177.

21 Lyons SE, Bruck ME, Bowie EJW, Ginsburg D. Impaired intracellular transport produced by a subset of type IIA von Willebrand disease mutations. J Biol Chem 1992; 267: 4424.

22 Dent JA, Berkowitz SD, Ware J, Kasper CK, Ruggeri ZM. Identification of a cleavage site directing the immunochemical detection of molecular abnormalities in type IIA von Willebrand factor. Proc Natl Acad Sci USA 1990; 87: 6306.

23 Furlan M, Robles R, Lämmle B. Partial purification and characterization of a protease from human plasma cleaving von Willebrand factor to fragments produced by in vivo proteolysis. Blood 1996; 87: 4223.

24 Tsai H-M, Sussman II, Ginsburg D, Lankhof H, Sixma JJ, Nagel RL. Proteolytic cleavage of recombinant type 2A von Willebrand factor mutants R834W R834Q: Inhibition by doxycycline and by monoclonal antibody VP-1. Blood 1997; 89: 1954.

25 Cooney KA, Nichols WC, Bruck ME et al. The molecular defect in type IIB von Willebrand disease. Identification of four potential missense mutations within the putative GpIb binding domain. J Clin Invest 1991; 87: 1227.

26 Randi AM, Rabinowitz I, Mancuso DJ, Mannucci PM, Sadler JE. Molecular basis of von Willebrand disease Type IIB. Candidate mutations cluster in one disulfide loop between proposed platelet glycoprotein Ib binding sequences. J Clin Invest 1991; 87: 1220.

27 Holmberg L, Dent JA, Schneppenheim R, Budde U, Ware J, Ruggeri ZM. von Willebrand factor mutation enhancing interaction with platelets in patients with normal multimeric structure. J Clin Invest 1993; 91: 2169.

28 Mazurier C. von Willebrand disease masquerading as haemophilia A. Thromb Haemost 1992; 67: 391.

29 Cacheris PM, Nichols WC, Ginsburg D. Molecular characterization of a unique von Willebrand disease variant. A novel mutation affecting von Willebrand factor/factor VIII interaction. J Biol Chem 1991; 266: 13499.

30 Eikenboom JCJ, Reitsma PH, Peerlinck KMJ, Briët E. Recessive inheritance of von Willebrand's disease type I. Lancet 1993; 341: 982.

31 Schneppenheim R, Budde U, Krey $\mathrm{S}$ et al. Results of a screening for von Willebrand disease type $2 \mathrm{~N}$ in patients with suspected haemophilia A or von Willebrand disease type 1 . Thromb Haemost 1996; 76: 598.

32 Weiss HJ, Ball AP, Mannucci PM. Incidence of severe von Willebrand's disease. N Engl J Med 1982; 307: 127.

33 Berliner SA, Seligsohn U, Zivelin A, Zwang E, Sofferman G. A relatively high frequency of severe (type III) von Willebrand's disease in Israel. Br J Haematol 1986; 62: 535.

34 Mannucci PM, Bloom AL, Larrieu MJ, Nilsson IM, West RR. Atherosclerosis and von Willebrand factor. I. Prevalence of severe von Willebrand's disease in western Europe and Israel. Br J Haematol 1984; 57: 163. 
35 Zhang ZP, Blombäck M, Nyman D, Anvret M. Mutations of von Willebrand factor gene in families with von Willebrand disease in the Aland Islands. Proc Natl Acad Sci USA 1993; 90: 7937.

36 Zhang ZP, Blombäck M, Egberg N, Falk G, Anvret M. Characterization of the von Willebrand factor gene ( $\mathrm{vWF}$ ) in von Willebrand disease type III patients from 24 families of Swedish and Finnish origin. Genomics 1994; 21: 188.

37 Mohlke KL, Nichols WC, Rehemtulla A et al. A common frameshift mutation in von Willebrand factor does not alter mRNA stability but interferes with normal propeptide processing. Br J Haematol 1996; 95: 184.

38 Rodeghiero F, Castaman G, Dini E. Epidemiological investigation of the prevalence of von Willebrand's disease. Blood 1987; 69: 454.

39 Werner EJ, Broxson EH, Tucker EL, Giroux DS, Shults J, Abshire TC. Prevalence of von Willebrand disease in children: a multiethnic study. J Pediatr 1993; 123: 893.

40 Miller CH, Graham JB, Goldin LR, Elston RC. Genetics of classic von Willebrand's disease. I. phenotypic variation within families. Blood 1979; 54: 117.

41 Nichols WC, Lyons SE, Harrison JS, Cody RL, Ginsburg D. Severe von Willebrand disease due to a defect at the level of von Willebrand factor mRNA expression: detection by exonic PCR-restriction fragment length polymorphism analysis. Proc Natl Acad Sci USA 1991; 88: 3857.

42 Eikenboom JCJ, Matsushita T, Reitsma PH et al. Dominant type 1 von Willebrand disease caused by mutated cysteine residues in the D3 domain of von Willebrand factor. Blood 1996; 88: 2433.
43 Orstavik KH, Magnus P, Reisner H, Berg K, Graham JB, Nance W. Factor VIII and factor IX in a twin population. Evidence for a major effect of ABO locus on factor VIII level. Am J Hum Genet 1985; 37: 89.

44 Gill JC, Endres-Brooks J, Bauer PJ, Marks WJ, Montgomery RR. The effect of $\mathrm{ABO}$ blood group on the diagnosis of von Willebrand Disease. Blood 1987; 69: 1691.

45 Sweeney JD, Novak EK, Reddington M, Takeuchi KH, Swank RT. The RIIIS/J inbred mouse strain as a model for von Willebrand disease. Blood 1990; 76: 2258.

46 Nichols WC, Cooney KA, Mohlke KL et al. von Willebrand disease in the RIIIS/J mouse is caused by a defect outside of the von Willebrand factor gene. Blood 1994; 83: 3225.

47 Mohlke KL, Nichols WC, Westrick RJ et al. A novel modifier gene for plasma von Willebrand factor level maps to distal mouse chromosome 11. Proc Natl Acad Sci USA 1996; 93: 15352 .

48 Mohlke KL, Purkayastha AA, Westrick RJ, Ginsburg D. Comparative mapping of distal murine chromosome 11 and human $17 \mathrm{q} 21.3$ in a region containing a modifying locus for murine plasma von Willebrand factor level. Genomics 1998; 54: 19.

49 Mohlke KL, Purkayastha AA, Westrick RJ et al. Mvwf, a dominant modifier of murine von Willebrand factor, results from altered lineage-specific expression of a glycosyltransferase. Cell 1998; 96: 111.

50 Ginsburg D, Bowie EJW. Molecular genetics of von Willebrand disease. Blood 1992; 79: 2507-19. 